\title{
Strategies to develop antivirals against enterovirus 71
}

Rei-Lin Kuo ${ }^{1,2}$ and Shin-Ru Shih ${ }^{1,2,3^{*}}$

\begin{abstract}
Enterovirus 71 (EV71) is an important human pathogen which may cause severe neurological complications and death in children. The virus caused several outbreaks in the Asia-Pacific region during the past two decades and has been considered a significant public health problem in the post-poliovirus eradication era. Unlike poliovirus, there is no effective vaccine or approved antivirals against EV71. To explore anti-EV71 agents therefore is of vital importance. Several strategies have been employed to develop antivirals based on the molecular characteristics of the virus. Among these, some small molecules that were developed against human rhinoviruses and poliovirus are under evaluation. In this review, we discuss the recent development of such small molecules against EV71, known drug resistance and possible solutions to it, and animal models for evaluating the efficacy of these antivirals.

Although further investigation is required for clinical applications of the existing candidates, the molecular mechanisms revealed for the inhibition of EV71 replication can be used for designing new molecules against this virus in the future.
\end{abstract}

\section{Introduction}

Enterovirus 71 (EV71) belongs to the genus Enterovirus of the family Picornaviridae. Since the virus was first isolated in California in 1969 [1], a number of EV71 outbreaks have been reported throughout the world, from North America and Europe to Australia and Asia. During the past two decades, the virus has seriously affected the Asia-Pacific area, becoming a public health concern in several countries within this area [2-5]. Most commonly, EV71 causes handfoot-and-mouth disease (HFMD) in children, which is considered a mild syndrome. However, some young children infected by the virus have developed severe neurological syndromes, such as aseptic meningitis, encephalitis, poliomyelitis-like paralysis, and even death [6]. For example, the 1998 outbreak in Taiwan resulted in 405 cases of severe neurological complications, pulmonary edema or hemorrhage, and myocarditis, with 78 deaths [3]. More recently, a large scale EV71 outbreak associated with HFMD, neurological symdrome, and fatal cases was

\footnotetext{
* Correspondence: srshih@mail.cgu.edu.tw

${ }^{1}$ Research Center for Emerging Viral Infections, Chang Gung University, 259

Wen-Hua 1st Road, Kwei-Shan, Taoyuan, Taiwan

${ }^{2}$ Department of Medical Biotechnology and Laboratory Science, College of

Medicine, Chang Gung University, Taoyuan, Taiwan

Full list of author information is available at the end of the article
}

reported in China [5,7]. Until 2012, fatal cases caused by EV71 infection were still described in Asia [8].

Similar to other human enteroviruses, such as poliovirus, the transmission of EV71 occurs through the fecal-oral route. The primary replication sites for the virus are presumed to be in the tonsils and intestinal lymphoid tissue. Therefore, the virus can be spread from the gastrointestinal tract of infected people for weeks. This may also explain why most EV71 isolates were recovered from throat swabs and stool specimens. However, clinical features have suggested that the virus can reach the central nervous system (CNS) of people suffering from EV71 infection $[5,9]$. The two explanations for how EV71 spreads to the CNS are that virus in the bloodstream somehow penetrates the blood-brain barrier, or that virus reaches the CNS via a neuronal route. Recently, a mouse study supported the proposition that the major transmission route to the CNS may be through retrograde axonal transport in neurons [10].

In past decades, in an effort to eradicate polio, a dramatic reduction of epidemics has occurred through effective vaccines and improvement in public hygiene. However, the emergence of EV71 infection has recently developed into a new threat to children, especially because there are no specific treatments or vaccines to combat this ailment. Supportive therapy is still the primary management for severe 
cases of EV71 infection. Other than symptomatic treatment, intravenous immunoglobulin (IVIG) is clinically used to neutralize the virus and to nonspecifically suppress inflammation. Nevertheless, although this treatment has been routinely applied to severe cases of EV71 infection, its efficacy requires further evaluation. Therefore, the development of specific antiviral strategies against EV71 has become an urgent issue for the protection of children from the hazards of EV71 infection.

\section{Biological characteristics of EV71}

Like poliovirus, the prototype virus in the family Picornaviridae, EV71 is a small non-enveloped virus that encloses a positive-sense, single-stranded RNA molecule of approximately 7.4 kilobases [11]. After initial infection, the virus particle attaches itself to receptors on host cells and releases its RNA genome into the cytoplasm. Two host proteins, scavenger receptor B2 and human P-selectin glycoprotein ligand-1, have been identified as cellular receptors for EV71 $[12,13]$. Once the genome enters the host cell, the viral RNA, which possesses an internal ribosomal entry site (IRES) and poly(A) tail, serves as mRNA and is translated by a cap-independent mechanism [14]. A single large polyprotein is first synthesized. The functional viral proteins are then generated through maturation cleavage mediated by viral proteases $2 \mathrm{~A}^{\text {pro }}$ and $3 \mathrm{C}^{\text {pro }}[15]$.

The viral RNA genome is not only the mRNA for viral protein translation, but it can also be the template for replication by the virus-encoded RNA-dependent RNA polymerase (RdRP), designated 3D. In the infected cell, viral RNA replication occurs within a vesicular membrane structure in the cytoplasm $[16,17]$. Other than the 3D protein, the viral $2 \mathrm{C}$ protein, which is highly conserved among human enteroviruses, has been identified as part of the viral replication complex within the vesicular membrane [17]. Thereafter, the progeny positive-stranded viral RNA is then packaged by viral capsid proteins to form a new infectious virion. Infection eventually initiates the apoptotic pathway by its $2 \mathrm{~A}^{\text {pro }}$ and $3 \mathrm{C}^{\mathrm{pro}}$ proteins and lyses the infected cell $[18,19]$. Newly produced viral particles are released from the lysed cell.

\section{Antivirals targeting virus entry}

Blocking virus entry is an ideal antiviral strategy. For example, to a certain extent, treating severe cases of EV71 infection with IVIG was partly dependent on its nonspecific neutralization of the virus [20]. Correspondingly, certain animal studies have shown that passive transfer of antiserum from immunized mice could provide protection against an EV71 challenge [21,22]. According to past research, among viral capsid proteins, neutralizing epitopes were located on the VP1 protein [23]. VP1 was also identified as the major receptor-binding protein after EV71 infection $[12,13]$. Thus, development of specific antibodies against the neutralizing epitope on the viral capsid protein VP1 could be a successful antiviral strategy.

The VP1 protein of poliovirus or rhinovirus has also been shown to form a canyon structure, which is important for receptor binding. In addition, conformational change of the VP1 protein is the crucial step for viral particle disassembly and release of viral RNA into the host cell. Therefore, designing small molecules that target VP1 may interfere with EV71 infection. Two molecules, pleconaril (Figure 1A) and pirodavir, were found to suppress rhinovirus replication by targeting the capsid protein [24-26]. One of the molecules, pleconaril, has already been applied to treat lifethreatening enterovirus infections [27]. To verify the specific efficacy of pleconaril against EV71, a mouse study was performed, which resulted in significant improvement of severe symptoms in infected 1-day-old mice [28]. However, the EV71 inhibition capacity of pleconaril could vary for different isolates of the virus. Shia et al. reported that pleconaril was nearly ineffective in neutralizing EV71 isolates from the outbreak in Taiwan [29].

By using the skeleton of pleconaril as a template, a computer-assisted drug design developed a new class of pyridyl imidazolidinones with anti-EV71 activity. Among the pyridyl imidazolidinones, one of the compounds, BPR0Z-194 (Figure 1A), demonstrated its effectiveness against EV71 replication [30]. In addition to VP1-binding small molecules, lactoferrin, which is an abundant ironbinding glycoprotein in colostrum, was found to inhibit EV71 by binding to VP1 [31]. Although lactoferrin has not been approved for therapeutic purposes, it could be considered an agent for preventing virus entry.

\section{Antivirals targeting enterovirus proteases $3 C^{\text {pro }}$ and $2 A^{\text {pro }}$}

Maturation cleavages are critical steps for EV71 protein synthesis. As for other human enteroviruses, $2 \mathrm{~A}^{\text {pro }}$ and $3 \mathrm{C}^{\text {pro }}$ are the key proteases for processing of the viral precursor polyprotein. Rupintrivir (Figure 1B) was originally developed to inhibit human rhinovirus infection by blocking its $3 C^{\text {pro }}$ activity [32]. In recent years, this compound was confirmed as an EV71 replication inhibitor through the blockage of its $3 C^{\text {pro }}$ activity [33-35]. In addition to rupintrivir, Compound 1 (Figure 1B), which has been shown to inhibit the human rhinovirus $3 \mathrm{C}$ protease, may be another candidate for EV71 treatment by suppressing EV71 3C ${ }^{\text {pro }}$ [36]. To further investigate the antagonism of $3 C^{\text {pro }}$, structure-based design could be highly practical, especially because the X-ray crystal structure of the EV71 $3 C^{\text {pro }}$ has recently been resolved [37].

$2 \mathrm{~A}^{\text {pro }}$, which cleaves both the viral polyprotein and translational factor eIF4GI for shutting off host-cell translation, is also considered an antiviral drug target for inhibiting EV71 replication. Unfortunately, no specific inhibitor has been developed for blocking this chymotrypsin-related protease. Nevertheless, the X-ray 


\section{A. Small molecules targeting on enterovirus VP1}<smiles>Cc1cc(CCCOc2c(C)cc(-c3noc(C(F)(F)F)n3)cc2C)on1</smiles>

Pleconaril<smiles>CCOc1nc2ccc(OCCC3CCN(c4ccc(C)nn4)CC3)cc2o1</smiles>

BTA798<smiles>O=C1N(CCCCCOc2ccc(Br)cc2)CCN1c1ccncc1</smiles>

BPROZ-194

\section{B. Small molecules targeting on enterovirus 3 Cpro}<smiles>C=CCC(C(=O)NC(/C=C/C(=O)OCC)CC1CCNC1=O)n1cccc(NC(=O)c2cc(C)on2)c1=O</smiles>

\section{Small molecules targeting on enterovirus RdRP}<smiles>NC(=O)c1ncn(C2OC(CO)C(O)C2O)n1</smiles>

Ribavirin<smiles></smiles>

\section{DTriP-22}

Figure 1 Structures of small molecules targeting EV71 proteins. We thank Dr. Johan Neyts for providing the structures of Pleconaril, BTA798, Rupintrivir, Compound 1, and Ribavirin.

crystal structures of $2 \mathrm{~A}^{\text {pro }}$ from 2 related viruses, human rhinovirus serotype 2 and Coxsackievirus B4, have disclosed the enzymatic active pocket of these proteases $[38,39]$. Because of their similarities in function and sequence, the catalytic triad EV71 $2 \mathrm{~A}^{\text {pro }}$ could be predicted as His-21, Asp39, and Cys-110. By combining the information from the structures and the predicted catalytic sites, the structure-based inhibitor design is still applicable. Moreover, antivirals targeting EV71 proteases should not only block viral protein maturation, but they may also assist in the protecting host proteins from protease degradation.

\section{Antivirals targeting the enterovirus RdRP complex}

Because the EV71 RNA genome is replicated by its RdRP, known as the $3 \mathrm{D}$ protein, targeting the $3 \mathrm{D}$ polymerase could be a potent strategy for specifically inhibiting EV71 replication. Nucleoside analogues, such as ribavirin (Figure 1C) and 2'-C-methylcystidine, have been studied most extensively as picornavirus polymerase inhibitors [40-43]. Furthermore, a non-nucleoside analogue, DTriP22 , which is a piperazine-containing pyrazolo $[3,4-d]$ pyrimidine derivative (Figure $1 \mathrm{C}$ ), was identified as an anti-EV71 agent. By selecting resistant viruses, DTriP-22 was shown to inhibit viral RNA replication by targeting 
the EV71 3D polymerase [44]. Additionally, aurintricarboxylic acid, which was originally reported to be an inhibitor for the replicases of $\mathrm{HCV}$ and SARS-CoV, also exhibits the ability to inhibit EV71 3D polymerase [45-47].

\section{Inhibition of EV71-IRES dependent translation}

Because EV71 mRNA does not have 5' cap structure, translation is dependent on its IRES element. Numerous studies have shown that EV71 IRES-dependent translation is highly controlled by IRES-specific transacting factors (ITAFs) [48]. In addition to the ITAFs of EV71 IRES, far upstream element binding protein 2 (FBP2) was reported to negatively regulate EV71 IRES activity by competing with an ITAF named PTB [49]. By employing proteins that destructively affect EV71 IRES, the replication of EV71 can be suppressed. This concept may provide a new strategy for antiEV71 development. For example, kaempferol, a type of flavonoid, has been shown to inhibit EV71 replication and its IRES activity by changing the composition of the ITAFs [50].

\section{Other small molecule antivirals targeting on EV71 replication}

Enviroxime was found as an anti-viral compound against the replication of rhinovirus and poliovirus [51]. By analyzing the enviroxime-resistant mutants, the target site of enviroxime was identified on viral protein $3 \mathrm{~A}$ [52]. The viral protein $3 \mathrm{~A}$ and its precursor $3 \mathrm{AB}$ play the key roles in formation of enterovirus replication complex $[53,54]$. Development of anti-vrials targeting on $3 \mathrm{~A}$ or $3 \mathrm{AB}$ may be a successful strategy for inhibiting EV71 replication. For example, AN-12-H5, which is a functionally enviroximelike compound, was shown to be a novel inhibitor to block EV71 replication in vitro [55].

\section{The potentiality of RNA interference}

RNA interference is a cellular post-transcriptional process in which gene expression is silenced in a sequence-specific manner. Based on this concept, artificially generated small, interfering RNAs (siRNAs) are widely applied to study gene function. Because siRNAs can effectively downregulate gene expression, virus sequence-specific siRNAs have been considered to be potential therapeutic agents. Several studies have shown that virus-specific siRNAs can successfully suppress the replication of human viruses, such as poliovirus, HIV-1, and HCV [56-59]. This technology has also been applied experimentally to the treatment of EV71 infection [60,61]. Scientists have employed a suckling mouse model to evaluate siRNA against EV71 in vivo, and an siRNA targeting the $3 \mathrm{D}$ region has been shown as a potential therapeutic approach [62].

\section{Modulation of host immunity and interferon treatment}

Innate immunity is the host's natural defense system against virus invasion. Production of type I interferons (IFNs), IFN$\alpha / \beta$, is the initial response of innate immunity and results in activation of IFN-stimulated gene expression to block viral replication. IFN- $\alpha$ has been used to treat HCV infection, but its application for enterovirus infection has not been established. To evaluate whether type I IFN has a therapeutic effect against EV71 infection, a recombinant murine IFN- $\alpha$ was administered to EV71-infected newborn mice, resulting in an increased survival rate [63]. Similar to the in vivo study, in vitro testing also demonstrated the potency of IFN- $\alpha 14$ in reducing EV71 replication [64]. Although it has been shown that EV71-encoded protease $3 \mathrm{C}$ could degrade interferon regulatory factor-9 (IRF9) which is involved in type I IFN downstream signaling, combination of IFN- $\alpha$ and $3 C^{\text {pro }}$ inhibitor, rupintrivir, for EV71 treatment was considered as a strategy to combat the IFN signaling inhibition [65]. By the in vitro study, the combination treatment showed a synergistic effect against EV71 replication [65]. According to these studies, type I IFN could be considered a potent anti-EV71 treatment. Nevertheless, a recent study demonstrated that EV71 2A $\mathrm{A}^{\text {pro }}$ could be an IFN antagonist, because it reduces the expression level of the type I IFN receptor [66], making it questionable whether type I IFN will be active against EV71 infection.

\section{Resistance to antiviral treatment}

Because the EV71 RNA genome is synthesized by its RdRP, which does not have proofreading activity for faithfully replicating viral RNA, mutations in the newly synthesized viral genome are frequently generated during replication. Thus, EV71 variants that present antiviral resistance phenotypes could often be selected during antiviral treatment. For example, the elucidation of the mechanism of action of DTriP-22 was based on the appearance of drug-resistant mutants and whole viral genome sequencing [44]. To address the drug resistance of EV71, the practicability of combination treatments learned from HIV therapy is worth further evaluation. Ideally, molecules selected for combination therapy should act through different mechanisms. Based on two recent studies evaluating combination therapy against EV71, several combinations successfully showed a synergistic effect in inhibiting EV71, such as the combination of IFN- $\alpha$ and rupintrivir and the combination of rupintrivir and an analogue of pirodavir, BTA798 (Figure 1A) [65,67]. Therefore, combination therapy could be a possible strategy to combat EV71.

\section{Animal models for testing drugs against EV71}

To verify the effectiveness of antivirals against EV71, animal studies are urgently required, in addition to in vitro experiments. Since Chumakov et al. established an experimental 


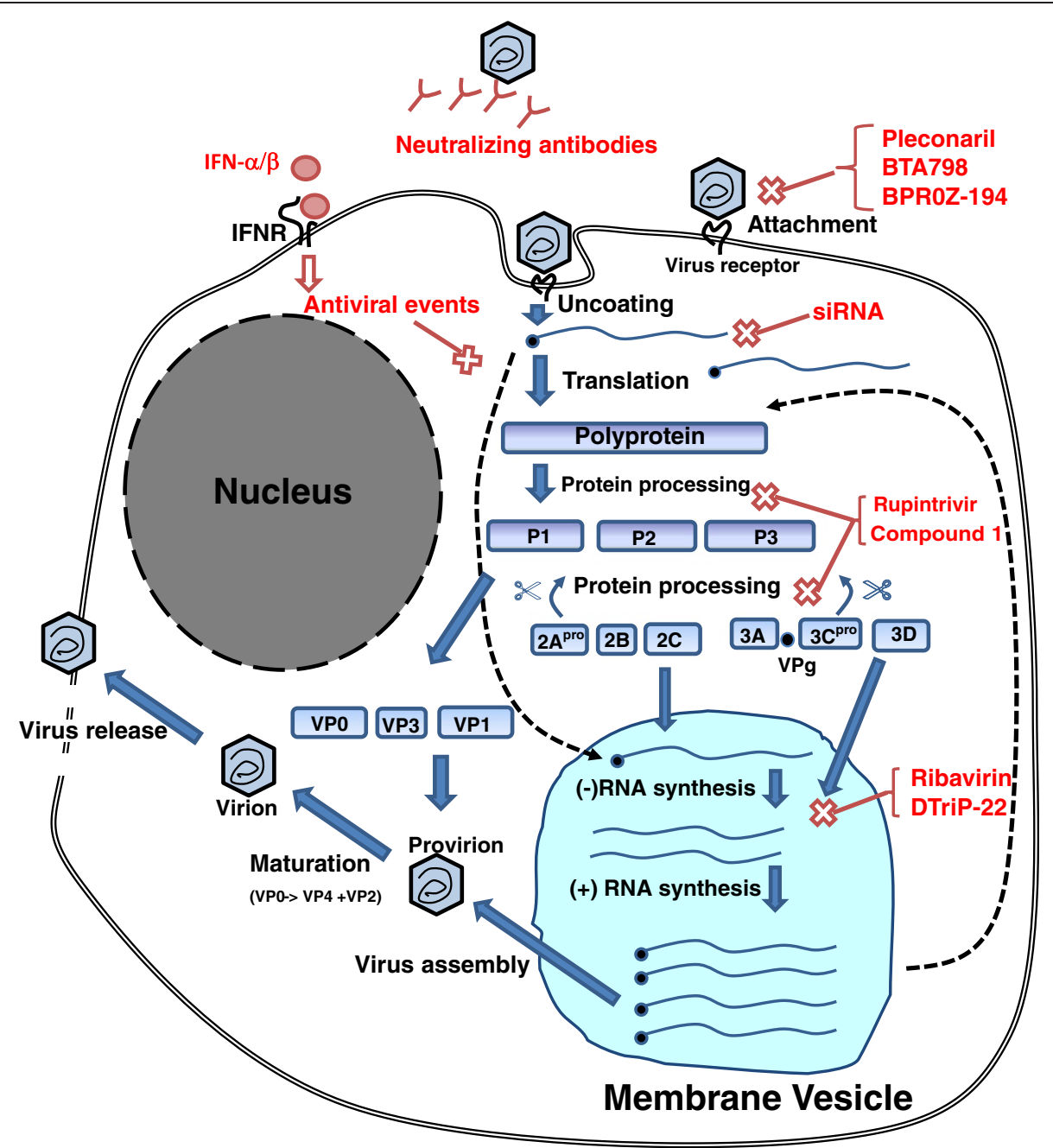

Figure 2 Overview of EV71 replication and molecular mechanisms of potential inhibitors. EV71 binds to its receptor on host cell and releases the genomic RNA into cytoplasm. Neutralizing antibodies bind to the receptor-binding capsid protein VP1 and prevent the virus-receptor interaction. VP1-binding small molecules, such as pleconaril, BTA798, and BPR0Z-194, can also interfere in virus entry. In cytoplasm, viral RNA can be targeted by virus-specific siRNAs for suppressing virus replication. A single large polyprotein is first synthesized and then cleaved by viral proteases $2 \mathrm{~A}$ and $3 \mathrm{C}$ to form functional proteins. Rupintrivir and Compound 1 can inhibit $3 \mathrm{C}$ protease activity to prevent maturation cleveage.

animal infection model, neonatal mice have been the most widely used for in vivo studies [68]. For example, in vivo studies were conducted using 1-day-old ICR mice to evaluate the protection of neutralizing antibodies against EV71 and to investigate CNS involvement after EV71 infection $[22,69]$. However, there are technical difficulties in handling 1-day-old pups for evaluating antiviral efficacy and toxicity. Additionally, a mouse-adapted EV71 strain was established by serial passage in mice. The mouse-adapted virus could infect 7-day-old ICR mice by oral inoculation and cause lethal CNS complications [70]. This tool therefore improved in vivo pathogenesis studies. Other than mice, cynomolgus monkeys have been used to study the neuropathogenicity of EV71 [71,72]. However, the mouse model with the mouse-adapted strain may be a relatively low-cost and effective solution for evaluating new antivirals.

\section{The developments of vaccine against EV71}

Based on the experience in the control of poliovirus epidemic, vaccination should be a primary strategy to prevent EV71 infection in children. Although there is no commercialized effective vaccine against EV71 available until now, several researches have disclosed the availability for the vaccine against EV71. For example, the viral capsid protein VP1 was initially designed as an immunogenic candidate for subunit vaccine [73-75]. In addition to VP1 subunit vaccine, the formaldehyde-inactivated whole-virus of EV71was also widely evaluated as a vaccine candidate $[76,77]$. However, several obstacles need to be overcome in the EV71 vaccine development. First of all, because of the lack in adult mouse model, most of the researches applied passive immunization strategies to verify the neutralizing antibody generated from immunized dams in the 
protection of the newborn mice. To overcome the limitation of the mouse model, the mouse-adapted strains of EV71 or EV71-receptor-transgenic mice may be applicable to the vaccine development. Since there are many genotypes of EV71 isolates based on the VP1 sequences, the selection for reference strain could be another obstacle for vaccine production. Therefore, it is urgent to establish the international collaboration for sharing the virology and epidemiological information. Nevertheless, a phase I clinical trial in human has been conducted to evaluate the safety and immunogenicity of a newly developed inactivated EV71 vaccine in China [78].

\section{Summary}

Over the past 2 decades, eradication efforts have substantially reduced the number of poliomyelitis cases worldwide. Unfortunately, reemerging EV71 infection has become another challenge for public health, especially in the AsiaPacific region. Unlike poliomyelitis, an effective EV71 vaccine is still not available to provide immunity in children. Therefore, development of anti-EV71 agents has become an urgent issue to relive distress in epidemic areas. Based on the replication characteristics of picornaviruses, several strategies have been developed for designing antivirals against EV71, as summarized in Figure 2. Certain antivirals originally developed against human rhinoviruses have been tested against EV71 because of the similarity in viral replication mechanisms. Because an experimental mouse model has been established, candidate anti-EV71 drugs can be further evaluated to assess therapeutic efficacy.

\section{Competing interests}

The authors declare that they have no competing interests.

\section{Authors' contributions}

RLK wrote the manuscript. SRS participated in its organization and coordination and helped to draft the manuscript. Both authors read and approved the final manuscript.

\section{Acknowledgements \\ The authors' researches are supported by grants NSC 100-2320-B-182-019- MY3 from the National Science Council in Taiwan and CMRPD1A0571 and CMRPD1A0671 from Chang Gung Memorial Hospital. We thank Dr. Johan Neyts for kindly providing the structures of Pleconaril, BTA798, Rupintrivir, Compound 1, and Ribavirin.}

\section{Author details}

${ }^{1}$ Research Center for Emerging Viral Infections, Chang Gung University, 259 Wen-Hua 1st Road, Kwei-Shan, Taoyuan, Taiwan. ${ }^{2}$ Department of Medical Biotechnology and Laboratory Science, College of Medicine, Chang Gung University, Taoyuan, Taiwan. ${ }^{3}$ Institute of Biotechnology and Pharmaceutical Research, National Health Research Institutes, Miaoli, Taiwan.

Received: 17 October 2012 Accepted: 2 January 2013

Published: 22 January 2013

\section{References}

1. Schmidt NJ, Lennette $\mathrm{EH}, \mathrm{Ho} H \mathrm{H}$ : An apparently new enterovirus isolated from patients with disease of the central nervous system. $J$ Infect Dis 1974, 129(3):304-309.

2. AbuBakar S, Sam IC, Yusof J, Lim MK, Misbah S, MatRahim N, Hooi PS: Enterovirus 71 outbreak, Brunei. Emerg Infect Dis 2009, 15(1):79-82.
3. Ho M, Chen ER, Hsu KH, Twu SJ, Chen KT, Tsai SF, Wang JR, Shih SR: An epidemic of enterovirus 71 infection in Taiwan. Taiwan Enterovirus Epidemic Working Group. N Engl J Med 1999, 341(13):929-935.

4. Shimizu H, Utama A, Yoshii K, Yoshida H, Yoneyama T, Sinniah M, Yusof MA, Okuno Y, Okabe N, Shih SR, et al: Enterovirus 71 from fatal and nonfatal cases of hand, foot and mouth disease epidemics in Malaysia, Japan and Taiwan in 1997-1998. Jpn J Infect Dis 1999, 52(1):12-15.

5. Yang F, Ren L, Xiong Z, Li J, Xiao Y, Zhao R, He Y, Bu G, Zhou S, Wang J, et al: Enterovirus 71 outbreak in the People's Republic of China in 2008. J Clin Microbiol 2009, 47(7):2351-2352.

6. Chang LY, Lin TY, Hsu KH, Huang YC, Lin KL, Hsueh C, Shih SR, Ning HC, Hwang MS, Wang HS, et al: Clinical features and risk factors of pulmonary oedema after enterovirus-71-related hand, foot, and mouth disease. Lancet 1999, 354(9191):1682-1686.

7. Zhang Y, Zhu Z, Yang W, Ren J, Tan X, Wang Y, Mao N, Xu S, Zhu S, Cui A, et al: An emerging recombinant human enterovirus 71 responsible for the 2008 outbreak of hand foot and mouth disease in Fuyang city of China. Virol J 2010, 7:94.

8. Seiff A: Cambodia unravels cause of mystery illness. Lancet 2012, 380 (9838):206.

9. Ooi MH, Wong SC, Lewthwaite P, Cardosa MJ, Solomon T: Clinical features, diagnosis, and management of enterovirus 71. Lancet Neurol 2010, 9(11):1097-1105.

10. Chen CS, Yao YC, Lin SC, Lee YP, Wang YF, Wang JR, Liu CC, Lei HY, Yu CK: Retrograde axonal transport: a major transmission route of enterovirus 71 in mice. J Virol 2007, 81(17):8996-9003.

11. Brown BA, Pallansch MA: Complete nucleotide sequence of enterovirus 71 is distinct from poliovirus. Virus Res 1995, 39(2-3):195-205.

12. Nishimura $Y$, Shimojima M, Tano $Y$, Miyamura $T$, Wakita $T$, Shimizu H: Human P-selectin glycoprotein ligand-1 is a functional receptor for enterovirus 71. Nat Med 2009, 15(7):794-797.

13. Yamayoshi S, Yamashita Y, Li J, Hanagata N, Minowa T, Takemura T, Koike S: Scavenger receptor B2 is a cellular receptor for enterovirus 71. Nat Med 2009, 15(7):798-801.

14. Thompson SR, Sarnow P: Enterovirus 71 contains a type I IRES element that functions when eukaryotic initiation factor elF4G is cleaved. Virology 2003, 315(1):259-266.

15. Racaniello VR: Picornaviridae: The Virus ans Their Repliation. In Fields Virology. 5th edition. Edited by Knipe DM, Howley PM. Philadelphia, PA, USA: Lippincott Williams \& Wilkins; 2007:796-839.

16. Rust RC, Landmann L, Gosert R, Tang BL, Hong W, Hauri HP, Egger D, Bienz $\mathrm{K}$ : Cellular COPII proteins are involved in production of the vesicles that form the poliovirus replication complex. J Virol 2001, 75(20):9808-9818.

17. Tang WF, Yang SY, Wu BW, Jheng JR, Chen YL, Shih CH, Lin KH, Lai HC, Tang $\mathrm{P}$, Horng JT: Reticulon 3 binds the $2 C$ protein of enterovirus 71 and is required for viral replication. J Biol Chem 2007, 282(8):5888-5898.

18. Lu CY, Lee CY, Kao CL, Shao WY, Lee PI, Twu SJ, Yeh CC, Lin SC, Shih WY, Wu SI, et al: Incidence and case-fatality rates resulting from the 1998 enterovirus 71 outbreak in Taiwan. J Med Virol 2002, 67(2):217-223.

19. Kuo RL, Kung SH, Hsu YY, Liu WT: Infection with enterovirus 71 or expression of its $2 \mathrm{~A}$ protease induces apoptotic cell death. J Gen Virol 2002, 83(Pt 6):1367-1376.

20. Chang LY, Lin TY, Huang YC, Tsao KC, Shih SR, Kuo ML, Ning HC, Chung PW, Kang CM: Comparison of enterovirus 71 and coxsackie-virus A16 clinical illnesses during the Taiwan enterovirus epidemic, 1998. Pediatr Infect Dis J 1999, 18(12):1092-1096.

21. Foo DG, Alonso S, Chow VT, Poh CL: Passive protection against lethal enterovirus 71 infection in newborn mice by neutralizing antibodies elicited by a synthetic peptide. Microb Infec 2007, 9(11):1299-1306.

22. Yu CK, Chen CC, Chen CL, Wang JR, Liu CC, Yan JJ, Su IJ: Neutralizing antibody provided protection against enterovirus type 71 lethal challenge in neonatal mice. J Biomed Sci 2000, 7(6):523-528.

23. Foo DG, Alonso S, Phoon MC, Ramachandran NP, Chow VT, Poh CL: Identification of neutralizing linear epitopes from the VP1 capsid protein of Enterovirus 71 using synthetic peptides. Virus Res 2007, 125(1):61-68.

24. Barnard DL, Hubbard VD, Smee DF, Sidwell RW, Watson KG, Tucker SP, Reece PA: In vitro activity of expanded-spectrum pyridazinyl oxime ethers related to pirodavir: novel capsid-binding inhibitors with potent antipicornavirus activity. Antimicrob Agents Chemother 2004, 48(5):1766-1772. 
25. Florea NR, Maglio D, Nicolau DP: Pleconaril, a novel antipicornaviral agent. Pharmacotherapy 2003, 23(3):339-348.

26. Hayden FG, Andries K, Janssen PA: Safety and efficacy of intranasal pirodavir (R77975) in experimental rhinovirus infection. Antimicrob Agents Chemother 1992, 36(4):727-732.

27. Rotbart HA, Webster AD: Treatment of potentially life-threatening enterovirus infections with pleconaril. Clin Infect Dis 2001, 32(2):228-235.

28. Zhang G, Zhou F, Gu B, Ding C, Feng D, Xie F, Wang J, Zhang C, Cao Q, Deng $Y$, et al: In vitro and in vivo evaluation of ribavirin and pleconaril antiviral activity against enterovirus 71 infection. Arch Virol 2012, 157(4):669-679.

29. Shia KS, Li WT, Chang CM, Hsu MC, Chern JH, Leong MK, Tseng SN, Lee CC, Lee YC, Chen SJ, et al: Design, synthesis, and structure-activity relationship of pyridyl imidazolidinones: a novel class of potent and selective human enterovirus 71 inhibitors. J Med Chem 2002, 45(8):1644-1655.

30. Shih SR, Tsai MC, Tseng SN, Won KF, Shia KS, Li WT, Chern JH, Chen GW, Lee CC, Lee YC, et al: Mutation in enterovirus 71 capsid protein VP1 confers resistance to the inhibitory effects of pyridyl imidazolidinone. Antimicrob Agents Chemother 2004, 48(9):3523-3529.

31. Weng TY, Chen LC, Shyu HW, Chen SH, Wang JR, Yu CK, Lei HY, Yeh TM: Lactoferrin inhibits enterovirus 71 infection by binding to VP1 protein and host cells. Antiviral Res 2005, 67(1):31-37.

32. Matthews DA, Dragovich PS, Webber SE, Fuhrman SA, Patick AK, Zalman LS, Hendrickson TF, Love RA, Prins TJ, Marakovits JT, et al: Structure-assisted design of mechanism-based irreversible inhibitors of human rhinovirus $3 \mathrm{C}$ protease with potent antiviral activity against multiple rhinovirus serotypes. Proc Natl Acad Sci U S A 1999, 96(20):11000-11007.

33. Lee JC, Shih SR, Chang TY, Tseng HY, Shih YF, Yen KJ, Chen WC, Shie JJ, Fang JM, Liang PH, et al: A mammalian cell-based reverse two-hybrid system for functional analysis of $3 \mathrm{C}$ viral protease of human enterovirus 71. Anal Biochem 2008, 375(1):115-123.

34. Lu G, Qi J, Chen Z, Xu X, Gao F, Lin D, Qian W, Liu H, Jiang H, Yan J, et al: Enterovirus 71 and coxsackievirus $\mathrm{A} 163 \mathrm{C}$ proteases: binding to rupintrivir and their substrates and anti-hand, foot, and mouth disease virus drug design. J Virol 2011, 85(19):10319-10331.

35. Tsai MT, Cheng YH, Liu YN, Liao NC, Lu WW, Kung SH: Real-time monitoring of human enterovirus (HEV)-infected cells and anti-HEV $3 \mathrm{C}$ protease potency by fluorescence resonance energy transfer. Antimicrob Agents Chemother 2009, 53(2):748-755.

36. Patick AK, Brothers MA, Maldonado F, Binford S, Maldonado O, Fuhrman S, Petersen A, Smith GJ 3rd, Zalman LS, Burns-Naas LA, et al: In vitro antiviral activity and single-dose pharmacokinetics in humans of a novel, orally bioavailable inhibitor of human rhinovirus $3 \mathrm{C}$ protease. Antimicrob Agents Chemother 2005, 49(6):2267-2275.

37. Cui S, Wang J, Fan T, Qin B, Guo L, Lei X, Wang M, Jin Q: Crystal structure of human enterovirus $713 \mathrm{C}$ protease. J Mol Biol 2011, 408(3):449-461.

38. Petersen JF, Cherney MM, Liebig HD, Skern T, Kuechler E, James MN: The structure of the $2 \mathrm{~A}$ proteinase from a common cold virus: a proteinase responsible for the shut-off of host-cell protein synthesis. EMBO J 1999, 18(20):5463-5475.

39. Baxter NJ, Roetzer A, Liebig HD, Sedelnikova SE, Hounslow AM, Skern T, Waltho JP: Structure and dynamics of coxsackievirus B4 2A proteinase, an enyzme involved in the etiology of heart disease. J Virol 2006, 80(3):1451-1462

40. Goris N, De Palma A, Toussaint JF, Musch I, Neyts J, De Clercq K: 2'-Cmethylcytidine as a potent and selective inhibitor of the replication of foot-and-mouth disease virus. Antiviral Res 2007, 73(3):161-168.

41. Harki DA, Graci JD, Galarraga JE, Chain WJ, Cameron CE, Peterson BR: Synthesis and antiviral activity of 5-substituted cytidine analogues: identification of a potent inhibitor of viral RNA-dependent RNA polymerases. J Med Chem 2006, 49(21):6166-6169.

42. Kishimoto $\mathrm{C}$, Crumpacker CS, Abelmann WH: Ribavirin treatment of murine coxsackievirus B3 myocarditis with analyses of lymphocyte subsets. J Am Coll Cardiol 1988, 12(5):1334-1341

43. Graci JD, Too K, Smidansky ED, Edathil JP, Barr EW, Harki DA, Galarraga JE, Bollinger JM Jr, Peterson BR, Loakes D, et al: Lethal mutagenesis of picornaviruses with N-6-modified purine nucleoside analogues. Antimicrob Agents Chemother 2008, 52(3):971-979.
44. Chen TC, Chang HY, Lin PF, Chern JH, Hsu JT, Chang CY, Shih SR: Novel antiviral agent DTriP-22 targets RNA-dependent RNA polymerase of enterovirus 71. Antimicrob Agents Chemother 2009, 53(7):2740-2747.

45. He R, Adonov A, Traykova-Adonova M, Cao J, Cutts T, Grudesky E, Deschambaul Y, Berry J, Drebot M, Li X: Potent and selective inhibition of SARS coronavirus replication by aurintricarboxylic acid. Biochem Biophys Res Commun 2004, 320(4):1199-1203.

46. Yap $Y$, Zhang $X$, Andonov A, He R: Structural analysis of inhibition mechanisms of aurintricarboxylic acid on SARS-CoV polymerase and other proteins. Comput Biol Chem 2005, 29(3):212-219.

47. Hung HC, Chen TC, Fang MY, Yen KJ, Shih SR, Hsu JT, Tseng CP: Inhibition of enterovirus 71 replication and the viral 3D polymerase by aurintricarboxylic acid. J Antimicrob Chemother 2010, 65(4):676-683.

48. Shih SR, Stollar V, Li ML: Host factors in enterovirus 71 replication. J Virol 2011, 85(19):9658-9666.

49. Lin JY, Li ML, Shih SR: Far upstream element binding protein 2 interacts with enterovirus 71 internal ribosomal entry site and negatively regulates viral translation. Nucleic Acids Res 2009, 37(1):47-59.

50. Tsai F-J, Lin C-W, Lai C-C, Lan Y-C, Lai C-H, Hung C-H, Hsueh K-C, Lin T-H, Chang HC, Wan L, et al: Kaempferol inhibits enterovirus 71 replication and internal ribosome entry site (IRES) activity through FUBP and HNRP proteins. Food Chem 2011, 128(2):312-322.

51. Wikel JH, Paget CJ, DeLong DC, Nelson JD, Wu CY, Paschal JW, Dinner A, Templeton RJ, Chaney MO, Jones ND, et al: Synthesis of syn and anti isomers of 6-[[(hydroxyimino)phenyl]methyl]-1-[(1-methylethyl)sulfonyl] $1 \mathrm{H}$-benzimidazol-2-am ine. Inhibitors of rhinovirus multiplication. J Med Chem 1980, 23(4):368-372.

52. Heinz BA, Vance LM: The antiviral compound enviroxime targets the $3 A$ coding region of rhinovirus and poliovirus. J Virol 1995, 69(7):4189-4197.

53. Hope DA, Diamond SE, Kirkegaard K: Genetic dissection of interaction between poliovirus 3D polymerase and viral protein 3AB. J Virol 1997, 71(12):9490-9498.

54. Giachetti C, Hwang SS, Semler BL: Cis-acting lesions targeted to the hydrophobic domain of a poliovirus membrane protein involved in RNA replication. J Virol 1992, 66(10):6045-6057.

55. Arita $\mathrm{M}$, Takebe $\mathrm{Y}$, Wakita $\mathrm{T}$, Shimizu H: A bifunctional anti-enterovirus compound that inhibits replication and the early stage of enterovirus 71 infection. J Gen Virol 2010, 91(Pt 11):2734-2744.

56. Kapadia SB, Brideau-Andersen A, Chisari FV: Interference of hepatitis C virus RNA replication by short interfering RNAs. Proc Natl Acad Sci U S A 2003, 100(4):2014-2018.

57. Novina CD, Murray MF, Dykxhoorn DM, Beresford PJ, Riess J, Lee SK, Collman RG, Lieberman J, Shankar P, Sharp PA: siRNA-directed inhibition of HIV-1 infection. Nat Med 2002, 8(7):681-686

58. Jacque JM, Triques K, Stevenson M: Modulation of HIV-1 replication by RNA interference. Nature 2002, 418(6896):435-438

59. Gitlin L, Karelsky S, Andino R: Short interfering RNA confers intracellular antiviral immunity in human cells. Nature 2002, 418(6896):430-434

60. Sim AC, Luhur A, Tan TM, Chow VT, Poh CL: RNA interference against enterovirus 71 infection. Virology 2005, 341(1):72-79.

61. Lu WW, Hsu YY, Yang JY, Kung SH: Selective inhibition of enterovirus 71 replication by short hairpin RNAs. Biochem Biophys Res Commun 2004, 325 (2):494-499.

62. Tan EL, Tan TM, Tak Kwong Chow V, Poh CL: Inhibition of enterovirus 71 in virus-infected mice by RNA interference. Mol Ther 2007, 15(11):1931-1938.

63. Liu ML, Lee YP, Wang YF, Lei HY, Liu CC, Wang SM, Su IJ, Wang JR, Yeh TM Chen $\mathrm{SH}$, et al: Type I interferons protect mice against enterovirus 71 infection. J Gen Virol 2005, 86(Pt 12):3263-3269.

64. Yi L, He Y, Chen Y, Kung HF, He ML: Potent inhibition of human enterovirus 71 replication by type I interferon subtypes. Antivir Ther 2011, 16(1):51-58.

65. Hung HC, Wang HC, Shih SR, Teng IF, Tseng CP, Hsu JT: Synergistic inhibition of enterovirus 71 replication by interferon and rupintrivir. $J$ Infect Dis 2011, 203(12):1784-1790.

66. Lu J, Yi L, Zhao J, Yu J, Chen Y, Lin MC, Kung HF, He ML: Enterovirus 71 Disrupts Interferon Signaling by reducing the Interferon Receptor I. J Virol 2012, 86(7):3767-3776.

67. Thibaut HJ, Leyssen P, Puerstinger G, Muigg A, Neyts J, De Palma AM: Towards the design of combination therapy for the treatment of enterovirus infections. Antiviral Res 2011, 90(3):213-217. 
68. Chumakov M, Voroshilova M, Shindarov L, Lavrova I, Gracheva L, Koroleva G, Vasilenko S, Brodvarova I, Nikolova M, Gyurova S, et al: Enterovirus 71 isolated from cases of epidemic poliomyelitis-like disease in Bulgaria. Arch Virol 1979, 60(3-4):329-340.

69. Chen YC, Yu CK, Wang YF, Liu CC, Su IJ, Lei HY: A murine oral enterovirus 71 infection model with central nervous system involvement. I Gen Virol 2004, 85(Pt 1):69-77.

70. Wang YF, Chou CT, Lei HY, Liu CC, Wang SM, Yan JJ, Su IJ, Wang JR, Yeh $\mathrm{TM}$, Chen SH, et al: A mouse-adapted enterovirus 71 strain causes neurological disease in mice after oral infection. $J$ Virol 2004, 78(15):7916-7924.

71. Nagata N, Shimizu H, Ami Y, Tano Y, Harashima A, Suzaki Y, Sato Y, Miyamura T, Sata T, Iwasaki T: Pyramidal and extrapyramidal involvement in experimental infection of cynomolgus monkeys with enterovirus 71 . J Med Virol 2002, 67(2):207-216.

72. Nagata N, Iwasaki T, Ami Y, Tano Y, Harashima A, Suzaki Y, Sato Y, Hasegawa $H$, Sata T, Miyamura T, et al: Differential localization of neurons susceptible to enterovirus 71 and poliovirus type 1 in the central nervous system of cynomolgus monkeys after intravenous inoculation. J Gen Virol 2004, 85(Pt 10):2981-2989.

73. Chen HL, Huang JY, Chu TW, Tsai TC, Hung CM, Lin CC, Liu FC, Wang LC, Chen YJ, Lin MF, et al: Expression of VP1 protein in the milk of transgenic mice: a potential oral vaccine protects against enterovirus 71 infection. Vaccine 2008, 26(23):2882-2889.

74. Chen HF, Chang MH, Chiang BL, Jeng ST: Oral immunization of mice using transgenic tomato fruit expressing VP1 protein from enterovirus 71 . Vaccine 2006, 24(15):2944-2951.

75. Wu CN, Lin YC, Fann C, Liao NS, Shih SR, Ho MS: Protection against lethal enterovirus 71 infection in newborn mice by passive immunization with subunit VP1 vaccines and inactivated virus. Vaccine 2001, 20(5-6):895-904.

76. Chen CW, Lee YP, Wang YF, Yu CK: Formaldehyde-inactivated human enterovirus 71 vaccine is compatible for co-immunization with a commercial pentavalent vaccine. Vaccine 2011, 29(15):2772-2776.

77. Ong KC, Devi S, Cardosa MJ, Wong KT: Formaldehyde-inactivated wholevirus vaccine protects a murine model of enterovirus 71 encephalomyelitis against disease. J Virol 2010, 84(1):661-665

78. Li YP, Liang ZL, Gao Q, Huang LR, Mao QY, Wen SQ, Liu Y, Yin WD, Li RC, Wang JZ: Safety and immunogenicity of a novel human Enterovirus 71 (EV71) vaccine: a randomized, placebo-controlled, double-blind, Phase I clinical trial. Vaccine 2012, 30(22):3295-3303.

doi:10.1186/1743-422X-10-28

Cite this article as: Kuo and Shih: Strategies to develop antivirals against enterovirus 71. Virology Journal 2013 10:28.

\section{Submit your next manuscript to BioMed Central and take full advantage of:}

- Convenient online submission

- Thorough peer review

- No space constraints or color figure charges

- Immediate publication on acceptance

- Inclusion in PubMed, CAS, Scopus and Google Scholar

- Research which is freely available for redistribution 